Матери и святого чюдотворца Никоды [lacuna] божии - помилуи нас ("By the prayers of Thy Most Pure Mother and holy wonderworker Nicholas [...] of God - have mercy on us"). Kirillin thinks that the lacuna might correspond to the word yzодника (Genitive form of one of the synonyms of "saint" in Church Slavonic and Old Russian, a normal epithet of St Nicholas). Instead, I am sure, the lacuna corresponds to the most common formula of the final clauses of such texts written with the titles, thus in a very compact form and without breaks between words: zи ие хе сне ("O Lord Jesus Christ Son"). This phrase contains the same number of letters (nine) as угодника (where the initial $/ \mathrm{u} / \mathrm{might}$ be rendered by the digraph oy). If so, the em-dash added by Kirillin is also out of place, and the text must be read as: За молитвъ пречистые ти Матери и святого чюдотворца Николы Господи Иисусе Христе Сыне Божий помилуи нас (“By the prayers of Thy Most Pure Mother and holy wonderworker Nicholas, O Lord Jesus Christ, have mercy on us").

Basil Lourié

\title{
Нина В. СиницынА, Сказания о преподобном Максиме Греке (XVI-XVII в6.) (Москва: Издательство ПСТГУ, 2006) 136 с. [Издание ПСТГУ-ИРИ РАН]
}

Nina Sinitsyna, Narration on St. Maxim the Greek (XVIXVII cent.) (Moscow, St. Tikhon University Publishers, 2006) 136 pp. ISBN 5-7429-0232-8

The book written by prominent Russian scholar Nina Sinitsyna deals with the earliest textual witnesses of the life of Maxim the Greek (Максим Грек) or Maximos Trivolis, an Athonite monk who was invited to Russia in 1518 and died there in 1555. Several pieces of hagiography subsist from the earliest period. All of them are published in the book. These are: Narratio-praefatio [сказание из корпуса] by an anonymous author, known in several redactions and Narratio informans [Сказаніе извъстно] known in many mss. The latter was included into the Menaion of the priest Ioann Milyutin (1646-1654).

Two additional text witnesses were added to these texts. One is a small note written down by monk Selivan, a disciple of Maxim (1524), the other by monk Nil Kurlyatev (1552). The main importance of the book however is a new edition of the Narratio informans according to the ms. recension of 1587. Now the hagiographical dossier of St. Maxim looks fairly complete. Some minor problems to be mentioned are 
related to the spelling of the titlo (abbreviations). Thus מئіо on p. 75 is most likely Давыдовы and not давидовы, likewise probably a titlo ii $\widehat{i}_{i}$ and should be spelled as доcka. Nevertheless, a very high level is maintained in the book, which could be labeled as a very helpful addition to the dossier of one of the most famous figures in the religious and cultural history of XVI century Russia.

A. Muraviev

П. И. ЖУРОВА, В.Ю. КРУТЕЦКИЙ, Н. В. СИНИЦЫНА, Б. Л. ФОНКИЧ, К. Хвостова (изд.), Преподобнъй Максим Грек. Сочинения. Том I (Москва: «Индрик», 2008) 568 с. [Российская Академия Наук: Институт Российской Истории, Сибирское отделение РАН: Институт Истории].

\section{I. Zhurova, V. Y. Krutetsky, N. V. Sinitsyna, B. L. Fonkich,} K. Khvostova (ed.), Saint Maxim the Greek. Collected Works. Volume I (Moscow: “Indrik publishers", 2008) 568 pp. [Russian Academy of Sciences: Institute of Russian History; Siberian Branch of RAS: The Institute of History]

ISBN 978-5-85759-445-2.

The first long-awaited volume of the new edition of the works of St Maxim the Greek has been published by renowned Moscow scholar Nina Sinitsyna in collaboration with one of the strongest teams working with pre-Peter texts and the old-believer tradition - the N. Pokrovsky group from Novosibirsk. The volume includes texts of the first period of the life of St Maxim in Russia until the condemnation (1518-1525) as well as works preserved in Greek (with Russian translation), written in Italy and on Mt Athos (1498-1516) by Michael (Maximos) Trivolis. The very identity of St. Maxim the Greek known from the Russian sources remained unclear until I. Denisov identified him as Maksimos Trivolis in 1943; since then his hypothesis has received general acknowledgement.

The first publication of the Greek part of the heritage of St Maxim will strongly contribute to the research of Maxim's relation to the Italian Renaissance. Although the problem itself remains somehow outside the focus of the introductory article, it remains pretty acute and demands tough work with Latin contemporary sources.

The new edition comes almost 150 years after the three-volume edition which was completed in 1859-1862 in the Kazan Theological 